\title{
A queda das ações no mercado dos afetos: medo, amor e solidão em Ana Luiza Escorel, Mariana Portella e Elvira Vigna
}

Lucia Helena $^{1}$

\begin{abstract}
A misteriosa fragilidade dos vínculos humanos, o sentimento de insegurança que ela inspira e os desejos conflitantes (estimulados por tal sentimento) de apertar os laços e ao mesmo tempo mantê-los frouxos, é o que este livro busca esclarecer, registrar e apreender.
\end{abstract}

Zygmunt Bauman

\section{A fragilidade dos laços humanos}

Nos dias de hoje não é algo de pouca monta tratar dos vínculos entre os humanos e falar de nossa fragilidade, solidão e necessidade de amor. Principalmente quando o terror está no ar. Entre outros momentos deploráveis, ele foi encenado em grande escala na primeira guerra do Golfo, em 16 de janeiro de 1991. Televisionada em cadeia planetária, ofereceu-se aos olhos do telespectador um show de alta tecnologia no qual, em altíssimos decibéis, mísseis eram lançados para o Oriente Médio em ares nunca antes atravessados daquela forma. Naquele momento, na sociedade globalizada, até a guerra virou um espetáculo.

O chamado September eleven 2001, como dizem os norte-americanos, foi um ataque terrorista indesculpável, é verdade, mas que buscava, entre outras coisas, revidar o poderio ocidental. Em 11 de setembro de 2001, o Pentágono e as Torres Gêmeas foram alvo de uma ação muito cruel e criminosa, que tem base no desespero, na loucura e na falta de capacidade de todos nós lidarmos com a diferença de maneira não fundamentalista.

Recentemente, na cidade luz, um dia chamada Paris capital do século XIX, em ato de louvor e amor por Walter Benjamin (2000), outro ataque terrorista cobre de azar uma sexta-feira 13 de novembro de 2015. E, com isso, o medo e o terrorismo se abateram sobre a cidade até então sorridente, iluminada, parisiense. A conhecida flânerie - que os franceses exportaram para o mundo com suas galerias e o luxo da Belle Époque até pelo menos 1920 - foi interrompida. Tiros, ataques inesperados,

\footnotetext{
${ }^{1}$ Doutora em letras e professora do Departamento de Letras Clássicas e Vernáculas do Instituto de Letras da Universidade Federal Fluminense (UFF), Niterói, RJ, Brasil. E-mail: 1.h@ globo.com
} 
armamento pesado e até armas caseiras, tudo se mistura e parece perdurar e se expandir, clamando pela Marselhesa.

Será o mundo em estado de guerra? Que revolução virá daí?

A tudo isso se acrescente a guerra do cotidiano das balas perdidas, da fome, do ebola de sociedades cães sem pluma, das quais vamos tirando tudo, até o que nunca tiveram. E das doenças infectocontagiosas cujo surto poderia ter sido evitado, não fosse a incúria administrativa que se espalha não só no Brasil e ameaça a saúde de gerações atuais e por vir, como a explosão da dengue, do chicungunha e do zika, que estão a exigir providências imediatas não só de instituições locais e nacionais como também de instituições mundiais da saúde.

Isso sem falar nas levas de refugiados tentando encontrar abrigo e que morrem às centenas, aos milhares de centenas, em busca da Europa e por ela rejeitados. Se a muitas vezes bilionária corrida espacial tivesse dado certo e sido descoberto um planeta habitável ou um asteroide qualquer, por certo, o rejeito humano teria nele um endereço óbvio. Ainda não conseguiram, felizmente.

Mas sempre temos um desastre "natural" aqui e outro ali, ceifando a miséria, os que não deram certo na corrida do capital a qualquer custo, como na tragédia do Rio Doce, cujo nome parece hoje um deboche e em cujas margens choram os que tiveram tudo soterrado, até as vidas. As mineradoras permanecem. A fiscalização não se fez e não se faz. E não se sabe se, e quando, será feita.

A impunidade é uma rosa dos ventos, assolando todos os cantões do planeta. E em nome do Deus cristão, judaico, muçulmano ou de ditaduras e absolutismos todos eles fundamentalistas, a luta entre o sacro e o que é profano aparece como desculpa para a desmedida dos homens em sua ambição desenfreada, falta de amor, intolerância e incapacidade de conviverem em paz, num mundo que tem por bandeira de fachada prestar culto à diferença e ao multiculturalismo.

Liga-se a esse panorama, embora não só a isto, o meu enorme interesse em examinar como a literatura atual tem tratado o tema do medo, do amor e da solidão dos seres na sociedade globalizada das duas últimas décadas. Conectado a este primeiro motivo, outro dado chama a atenção: o fato de que o medo vem assumindo um papel enorme, faz tempo, na vida social planetária e no enfraquecimento dos laços de afeto. Não se consegue, no cotidiano dos afazeres, "estar unido, atado e firme", conforme ponderava o poema atribuído a Gregório de Matos. 
A ficção, não só deste século, mas desde sempre, tratou de amor e guerra. Lembremo-nos de Sherazade, que, por medo de morrer e pela incapacidade de amar do Sultão, contou-lhe histórias para prolongar sua vida. Homero é outro que sabia disso como ninguém, colhendo na sabedoria milenar dos povos da antiguidade as fábulas que transformou em obras ainda hoje vivas.

Vivendo um agora que nunca foi tão curto, é urgente pensar o presente, ainda que as lentes para isto sejam próximas demais e insuficientes. Foco, assim, o romance brasileiro contemporâneo, em especial os que tratam da questão do medo de amar e da fragilidade dos elos de afeto na construção dos personagens de obras intensas e fundamentais. Neles percebo o tanto de temor, amor e guerra que se engendram, dentro e fora do cotidiano sem nobreza de personagens magníficos, o que não quer dizer grandiosos, mas até talvez inexpressíveis, no aqui e agora da contemporaneidade.

$\mathrm{O}$ tanto de medo, temor, ansiedade que se encontra nessas narrativas leva a que se faça referência, nesta introdução, a dois trechos de duas escritoras, uma portuguesa e outra brasileira, que, desde que os li, ficaram ecoando em minha memória como indeléveis cristais brilhantes, como ideias aladas que me acompanham sem desistir de mim. A elas me rendo.

Refiro-me às escritoras - das quais não vou tratar neste artigo Maria Gabriela Llansol e Clarice Lispector. As duas participam como inspiração para lembrar de meu primeiro contato com o poder do medo. Sem confiar inteiramente na memória, fui rever os textos e cito os dois fragmentos a que estou me referindo. O primeiro vem de Maria Gabriela Llansol (1977) e foi extraído de O livro das comunidades: "Há três coisas que me metem medo: a primeira, a segunda e a terceira".

O segundo vem de Lispector e foi extraído do conto "Imitação da rosa", do livro Laços de família. Retomo a passagem na qual o narrador mostra a personagem Laura angustiada, como se falasse consigo mesma em busca de tranquilizar-se, ao enumerar três de seus afazeres, neles tentando agarrar-se como se fossem uma tábua de salvação: "1ㅇ, calmamente vestir-se; 2o, esperar Armando já pronta; 3o, o terceiro, o que era? Pois é" (Lispector, 1965, p. 31).

Nos dois fragmentos, encontram-se duas formas insólitas de manifestação do temor. Em Llansol, o conhecimento do impacto de algo estranho e inesperado, pois o que se enumera como um, dois e três não esclarece nada, deixando em suspense o conteúdo do medo. Em 
Lispector, a primeira e a segunda tarefas de Laura remetem a algo estabelecido, racional. Mas, de súbito, a terceira tarefa lança o leitor no vazio, abrindo-se um fosso na lucidez, porque, em vez de um conteúdo para o medo, salta uma pergunta: e "o terceiro, o que é?"

A resposta que não chega põe o leitor em estado de vigília, revelando-se ainda mais a instabilidade da personagem. Proveniente desse estado de desequilíbrio, um estranhamento se introduz no nível da pré-fala da personagem, que o foco narrativo consegue captar. E é nesta dimensão que o insólito se constrói.

Do fragmento emerge um bom exemplo do que diz Robert Humphrey (1976), em O fluxo da consciência, quando, ao abordar obras de Virgínia Woolf, James Joyce e Kathrin Mansfield, entre outros, trata do nível da pré-fala. Este é por Humphrey considerado uma instância que, introduzindo-se repentinamente no discurso, deixa incidir o fluxo do pré-consciente da personagem, que se infiltra no discurso dos focalizadores ou dos narradores do texto (Bal, 1985, p. 119).

Em Lispector, tal desarranjo no enunciado ocorre em função da tentativa da personagem de domar a fera do perigo, driblando o medo ocasionado por seu desassossego. O desconserto provém da lida malsucedida de Laura com um trauma que a obseda e se manifesta nesse processo, que obedece a outra lógica. Com o recurso, Lispector rasura o etnocentrismo do pensamento ocidental que, implacável, apresenta-se como perspectiva universal. E aprofunda mais ainda o artifício, de modo borgiano, rompendo a possibilidade de se conseguir uma taxonomia capaz de tudo classificar e de dispor em escaninhos as ideias, os conceitos, vidas e experiências, como se fossem roupas que se estendem no varal e depois se arrumam nas gavetas.

Nas duas passagens das escritoras, surge um mundo que lida com o inconcluso, com a força e autonomia do ficcional, e o que era para ser simples, linear, ordenado - ou seja, a expectativa de ordem - acaba por se desordenar em um cruzamento arrebatado com o paradoxo. O leitor, nos dois casos (Llansol e Lispector) está na seara da vertigem da lucidez e na impossibilidade de se manter no registro do discurso direto ou indireto, entrando na cadeia complexa do discurso indireto livre e suas diversas técnicas, que Humphrey estuda e esclarece com brilho.

Llansol e Lispector estão no início de um processo de dessacralização e de abalo das relações fixas e estabelecidas não só no regime da frase, mas na compreensão dos lugares prontos, ou seja, nos clichês que 
separam diametralmente o feminino e o masculino, especialmente nas décadas de 1960 a 1980. Com elas, as duas personagens são apresentadas como casos de uma subjetividade no limiar, capaz de saltar por descuidada fresta semântica.

Desligando-se do rastro de Lispector e de Llansol e desenvolvendo um modo próprio de tratar do assunto, temos obras que recorrem à alegoria, como em Anel de vidro (Escorel, 2013), apelam ao surrealismo e à melancolia, como O outro lado da sombra (Portella, 2014), ou buscam um novo tipo de realismo, segundo quer Schøllhammer, como O que deu para fazer em matéria de história de amor (Vigna, 2012), em que se objetivam as emoções, vigiando-se as explosões do afeto.

Se os textos de Portella e Vigna não descartam o insólito no campo das relações humanas, o estranho não é, por sua vez, uma categoria fundamental em Anel de vidro. Os jogos amorosos ambíguos dois quais trata Escorel entram na ganga bruta das lutas miúdas e menores do dia a dia, emplacados na carnadura concreta das vidas e do íntimo dos personagens em uma narrativa lírica, se assim se pode dizer. Nessa confluência de gêneros literários, em muito se distingue o texto de Escorel das outras duas escritoras de que este artigo vai se ocupar lateralmente, dedicando-se a dar mais ênfase no momento ao romance de Escorel.

Se o mundo em que habitam as personagens de Llansol e Lispector já parecia fora dos eixos, apesar dos fixos padrões de gênero (no caso significando gender) que ainda eram socialmente obedecidos, e contra o qual elas corajosamente investem, Ana Luísa Escorel amplia esse caminho, procurando conectá-lo a novas sendas, ao tratar do medo, do amor e da solidão. Na epígrafe deste artigo, partimos de uma passagem de Zygmunt Bauman, ${ }^{2}$ extraída de Medo líquido. Fixo-me na palavra líquido. $\mathrm{O}$ vocábulo adjetiva uma série de obras do autor. Não se trata, no entanto, de um mero adjetivo gratuito e repetitivo, já que insiste, como categoria de pensamento filosófico, como se pode ver, em vários de seus livros, tais como: Modernidade líquida, Amor líquido, Medo líquido, Vida líquida. Com este recurso, Bauman tem destacado que o sentimento de

\footnotetext{
${ }^{2}$ Zygmunt Bauman é um sociólogo polonês. Iniciou sua carreira em Varsóvia, onde ocupou a cátedra de sociologia geral. Teve artigos e livros censurados e, em 1968, foi afastado da universidade. Em seguida, imigrou da Polônia para o Canadá, Estados Unidos e Austrália, até chegar à Grã-Bretanha, onde se tornou titular de sociologia da Universidade de Leeds de 1971 a 1991. Atualmente, é professor titular de sociologia das universidades de Leeds e Varsóvia. Recebeu o Prêmio Amalfi (1989) por Modernidade e holocausto, e o Prêmio Adorno, pelo conjunto da obra, em 1998.
} 
temor está impresso no que se vive (e como se vive) no período da globalização, por ele também chamado de fase líquida ${ }^{3}$ do moderno. Período que se teria iniciado por volta dos anos 1960, como estudou Daniel Bel, e que se caracterizou pela mudança do fordismo para um tipo de formação industrial fluida, não mais centrada na solidez da fábrica.

Não se pode mais sonhar com a melhor distribuição dos lucros, como um dia propôs Ford, não por bondade para com o trabalhador de sua fábrica de automóvel, mas para que este operário engordasse a ordem dos consumidores, criando-se um tipo de burguesia de segundo grau. No capitalismo líquido não há lugar para este tipo de ação. Ele irá se basear na terceirização e no barateamento dos contratos de trabalho, cada vez mais inseguros para o empregado. Líquido, portanto, é uma metáfora conceitual, não mero epíteto atribuído por Bauman, e remete à ideia de que a fase das estratégias que mantiveram o capitalismo sólido está à deriva. Rompe-se a fixidez de um modelo que tenderia daí em diante a acabar com os limites da fábrica, em uma nova prática de produção, diversificando-se, por exemplo, os locais de montagem, configurando-se a estrutura de um polvo: uma cabeça administrativa, com seus diversos tentáculos estendidos pelo mundo, buscando mercados baratos para produzir e aumentar os lucros da administração central, feita em geral por bolsas de valores e conglomerados anônimos.

Isso afeta grandemente a reflexão de Bauman, que tenta entender os fenômenos provenientes das novas condições de produção. Para explicar o que ocorre, Bauman coloca com didatismo e em perspectiva histórica o contexto da produção de bens materiais e espirituais das sociedades do mundo planetário, bem como dá relevo ao sentimento de dispersão, fragilidade e medo que se dissemina.

\section{Anel de vidro}

Para estudar Ana Luisa Escorel, decidi pensar essa situação, presente em sua obra, recorrendo à reflexão de Bauman, não por conceber as obras literárias como um reflexo do real ou das relações econômicas,

\footnotetext{
${ }^{3} \mathrm{O}$ capitalismo líquido, em oposição ao capitalismo sólido, é o que se baseia em novas relações e produções que se transformam tanto no que diz respeito ao local de produção, que não é mais o de uma grande extensão territorial na qual se construíam fábricas enormes e possantes, quanto no que concerne às relações empregatícias cuja legislação trabalhista foi "flexibilizada" para que se pudessem garantir, dizem, empregos, e também, mesmo que não o digam, maiores lucros ao produtor.
} 
mas, antes, para não deixar de lado a evidência de que produzimos bens espirituais dentro de um processo cuja historicidade afeta a todos e a tudo o que fazemos, sentimos e almejamos, seja de modo consciente ou inconsciente. Não é à toa que pesquisadores têm-se dedicado a estudar as relações entre memória, ficção e trauma.

Foi assim que o medo se tornou figurinha fácil nos nossos estudos e leituras, um ou o laço forte a ser examinado, uma vez que atua na construção do estilo, dos pensamentos das personas que a narrativa de Escorel cria, como um modo próprio de conduzir sua escrita no mundo híbrido da ficção contemporânea - tomando-se aqui este termo no sentido de Agamben. ${ }^{4}$

Como propõe Bauman em Amor líquido, pode-se dizer que em Anel de vidro os personagens são colocados em face da enorme fragilidade dos vínculos humanos, do sentimento de insegurança e dos desejos conflitantes de, ao mesmo tempo, apertar e afrouxar os laços de afeto que mantêm. $\mathrm{O}$ livro dedica-se a trabalhar "os riscos e ansiedades de se viver junto e separado, em nosso mundo líquido moderno" (Bauman, 2004, p. 13).

Descrença na unidade, pela ameaça das trocas constantes e não culposas de parceiros faz com que as personagens, quando muito, desemboquem em ilhotas de segurança, nas quais o que se encontra são mais momentos de solidão e de medo de vínculos fortes e de afinidades que possam ameaçar a liberdade individual e solitária, narcísica até -

\footnotetext{
${ }^{4}$ Como a denominação "contemporâneo/a" é larga, merece delimitação e esclarecimento. Ela não deve ser reduzida à estatura de um elenco do que foi publicado no presente, de maneira tosca e/ou ingênua, uma vez que com o termo sugere-se neste estudo uma forma complexa de encarar a temporalidade, que não possui apenas uma face vincada no "aqui e no agora". Saindo do binarismo da seta teleológica e abandonando a causalidade mecânica, falar do contemporâneo exige retomar a fértil consideração de Giorgio Agamben, para quem o contemporâneo encara a infinidade e o fragmento; a unidade interrompida do sentido que surge repentinamente, como se fosse produzido por vetores em fluidez e velocidade, que compõem e recompõem as transformações não lineares nem teleológicas do tempo, do saber e da reflexão humanos. A expressão contemporâneo/a não traduz apenas a significação de um tempo novo e/ou novidadeiro, mas a de um tempo no qual, num mesmo instante, podem relampejar fragmentos, ruínas, memórias de um passado que não passou totalmente, assim como relampejam as intuições do que ainda não está presente com clareza. Pensar o que vem a ser o contemporâneo constitui, finalmente, apreender que no paradigma do atual se tangenciam, interpenetram e intertrocam paradigmas passados e presentes que, no entanto, ainda vigem, têm força e vivificam no momento do que é chamado o aqui e agora. Ressalte-se, todavia, que com isso não se quer falar que o passado volta tal qual era. Não é isso. Trata-se de uma nova atualização do paradigma aparentemente passado que, ao se repetir, repete-se em diferença, como propõe Deleuze em Repetição e diferença (Agamben, 2009).
} 
como no momento final do romance - que alicerça o fundamento dos atos de escolha, que consiste ao mesmo tempo no poder de sedução e de sua perda. É muito grande, ao mesmo tempo, a necessidade de fincar raízes e a vontade de liberdade e solidão, o que torna a narrativa parceira e prisioneira do paradoxo e do labirinto. Como diz Walnice Nogueira Galvão, acerca da autora e de sua obra, na primeira resenha que se fez do romance:

Seu temperamento de escritora pende para o analítico, o que já era de notar nas memórias, mas se acentua neste romance. Nele estamos às voltas como uma prospeç̧ão, desencantada e lúcida, tendo por alvo a descartabilidade do casamento. Já se vê que o título é mais do que pertinente. [...] Dessa maneira, "Anel de vidro", escolhendo o vínculo mais ou menos duradouro - conforme a perspectiva, mais ou menos volátil - entre mulheres e homens, na craveira do que há de proteico nesse vínculo, debruça-se sobre suas metamorfoses, flagrando um momento de crise da instituição (Galvão, 2014).

Em quatro partes, como se fosse pintar um painel de unidades autônomas e ao mesmo tempo interligadas, divide-se a narrativa de Anel de vidro. Estas partes tratam de quatro diferentes personalidades: duas mulheres e dois homens. Nenhuma das personagens tem um nome de batismo, mas um epíteto, e todos os capítulos são narrados em terceira pessoa, procurando-se, assim, conter a extrema subjetividade que poderia existir numa narrativa do ponto de vista íntimo. $\mathrm{Na}$ primeira parte fala-se de uma mulher, que atende pela alcunha de "a assessora"; na segunda nos é apresentado o ponto de vista de um homem, chamado "o chefe"; na terceira, tem-se em perspectiva a "mulher do chefe"; e, na quarta, um homem, o "marido da assessora".

Quem foi criança nos anos de 1950, brincou com uma cantiga de roda, que dizia mais ou menos assim: "O anel que tu me deste era vidro e se quebrou e o amor que tu me tinhas era pouco e se acabou". As crianças a entoavam sem perceber que a quadrinha colocava em pauta a quadrilha do amor, que um dia teve em Drummond seu supremo bardo irônico, a sublinhar o desconcerto e a falibilidade frágil dos elos do amor. Lili, no poema de Drummond, não sem humor intitulado "Quadrilha", casavase com J. Pinto Fernandes, que nada tinha a ver com a história.

As personagens de Anel de vidro parecem ter lido Drummond. No entanto, à maneira das alegorias, não têm nome próprio, antes tipificam no singular um universal concreto. Ou seja, uma determinada unidade 
que vale por um conjunto. São personagens-tipo, transportam valores grupais que, agregados num indivíduo, representam uma categoria e expressam sua historicidade e classe também. No entanto, na criação de Escorel, a narrativa em terceira pessoa e a alegoria fazem, à maneira de Benjamin, falar o outro reprimido pela tipificação. As quatro personagens são viradas do avesso, não por uma narrativa psicologista, mas pelo minimalismo composicional de Escorel, que vai ter na frase, na sutil adjetivação, no jogo da linguagem do gênero, que recebe uma saraivada crítica em filigrana, uma forma raríssima de estrutura em abismo.

Cada uma das partes é um vértice de uma relação complexa, que envolve quatro personagens em um triângulo amoroso; personagens oriundas de relações que se queriam duradouras, mas que se extenuam, sempre vulneráveis às crises que, passageiras na superfície, vão abrindo o abismo da incomunicabilidade entre os pares, que têm na metamorfose e na fragilidade o seu grau de constituição, desgaste e destruição. $\mathrm{O}$ livro aborda o arranjo de dois casais, em uma narrativa que pende ao analítico, ao minucioso, numa prospecção ao mesmo tempo lúcida e talvez ácida dos laços matrimoniais, mais instáveis e descartáveis do que se desejaria fossem. O título, com sua memória infantil, faz o oposto da apologia da ingenuidade dos sonhos e da idealização. Cada uma das partes, que vem apenas numerada num índice lacônico $(1,2,3,4)$, é submetida a arranjos e permutações, "por um narrador que fica de fora, manejando a terceira pessoa da maneira mais rente possível ao protagonista de cada uma delas" (Galvão, 2014. p. 4).

O ponto de vista da narrativa é rico. Foge do naturalismo em moda, seja ele chamado de novo realismo, por alguns críticos. Sem retomar o exame de personagens em profundidade, o tema é tratado com aguda sutileza. Não há laivos românticos e descabelados, nenhum melodrama, nem arrancar de cabelos de mulheres desesperadas. Mas um clima de desalento, algumas vezes, emerge pela lente de longo alcance da focalização narrativa. É tão boa a obra que vem a ganhar, merecidamente, o Prêmio São Paulo de Literatura 2015, concedido a uma autora que começa a escrever ficção tardiamente, na quadratura dos 60 e poucos anos.

A narrativa é reflexiva e tem o lírico, a condensação, como o outro da prosa. A delicadeza das imagens, a frase como renda, a construção frasal de um imaginário feminino que se mistura com masculino vem logo na primeira página, com uma mulher ao mar. Sem falar de influência, não há como nos esquecermos da personagem de Uma 
aprendizagem ou o livro dos prazeres, de Lispector, com Lori entrando mar e, ao engolir de suas águas, associá-las ao líquido espesso de um homem. Só que nessa narrativa, a praia remonta a uma cantiga de amigo, com a amada sentindo na areia a textura macia do pó de arroz:

A praia era outra - areia áspera, ondas frias -, o litoral mesmo. Apenas muito abaixo na imensa costa amparada pelo mar. Tempos atrás a sensação parecida: imersa até as narinas na água morna, filho pequeno, e o marido lá com os amigos sobre os grãos macios, textura de pó de arroz. (Escorel, 2013, p. 9).

Com sua habilidade minimalista, a narrativa revela, com dois adjetivos em antonímia (areia áspera e ondas frias; água morna e grãos macios) a situação emperrada e de desagrado da relação matrimonial. Os casais não vivem em um "mar de rosas". É assim que, num movimento de metamorfose lírica da prosa, o interno carrega o externo e se funde com ele. A natureza está fora, mas diz do interior das personagens. Esta "falha" da oposição natureza versus cultura é uma forma de dar ao texto uma carnadura material que faz da palavra uma textura da subjetividade que se desenterra das paragens profundas de uma escavação sem fundo da melhor qualidade.

O medo e o temor são componentes de um exame acurado das relações sociais pelo viés das relações pessoais dos personagens do triângulo amoroso. A assessora, por exemplo, segundo a narrativa, observa corrosivamente as a matrizes autoritárias das relações de matrimônio, de poder e da política no Brasil. Assim é que se expõem os jogos desprezíveis de "uma classe dominante recente, marcada pela fidelidade ao chefe, no esforço de modernizar o país daquela maneira entre truculenta e ardilosa" (Escorel, 2014, p. 23). A sogra, por sua vez, inescrupulosamente, também rompe com os ditames do poderio externo dos homens. No caso, é ela quem representa o papel do clichê atribuído ao masculino, pois:

dirigia com mão de ferro o jornal da família, interferindo, inclusive, no teor dos editoriais; contratava e punha porta a fora qualquer funcionário; [...] Era a sogra, enfim, quem se preocupava com o crescente distanciamento da nora frente às tarefas próprias de um grupo como o que a moça passara a integrar, muitíssimo bem colocado na hierarquia social da região (Escorel, 2013, p. 10).

Do ponto de vista da mulher do chefe, os jogos de poder também são examinados. Mulher decidida, de classe alta, ao contrário da sogra da assessora, procura rever seu autoritarismo, dando lugar ao talvez, ao 
reexame de que seu desprezo pela tibieza das pessoas, o que, se era eticamente correto, relacionava-se não apenas com esta "qualidade" - a ética - mas também com os cacoetes autoritários da cultura na qual fora educada, em que "o tempo verbal usado por gente do seu meio social seguia sendo o imperativo" (Escorel, 2013, p. 132).

No que concerne ao chefe da assessora, ele parece romper com o clichê do masculino quando, ao analisar o comportamento de sua esposa ao descobrir que ele estava tendo um caso com outra mulher, põe-se face a face com os vínculos meio frouxos, um canal que se rompera entre os dois, ao longo do casamento. No entanto, logo a seguir, descobre dentro dele a vontade de que:

Apesar do peito confuso não estava pronto para abrir mão da mulher. O que precisava mesmo era ficar com as duas, ou quem sabe, juntar a elas uma terceira, uma quarta e uma quinta que porventura lhe cruzassem o caminho, naquele ponto da vida em que tudo estava pedindo para ser revisto de alto a baixo. [...]. Andava atrás de calor humano ligações livres - leves - com quem surgisse. Compromisso: nenhum. Sensações agradáveis em sucessão contínua, encadeadas como nas correntes de metal em que os elos não servem para nada se não tiverem outro, solidário, ao lado (Escorel, 2013, p. 94).

Adensado pela fragilidade, pelos sonhos de liberdade e pelo medo da solidão de seus personagens, Anel de vidro é um texto magnífico, que considera, como poucos de seu tempo, os fortes indícios de que, de fato, "o que fosse sólido desmancharia no ar" (Escorel, 2013, p. 95). Como se pode ver ao longo do romance, o interesse maior reside em focalizar a lenta corrosão dos laços de um pacto que se desgasta, na busca de substituir, como diz Walnice, um parceiro por outro. Medo, solidão e angústia são comparsas dessas metamorfoses do desejo e da impermanência de homens e mulheres, seja numa época instável, seja na sua própria inconstância. Como observa Noemi Jaffe, Anel de vidro revela o domínio sobre os detalhes, redes narrativas e vozes diferenciadas. "Mas um narrador menos controlador talvez permitisse que este 'anel de vidro' se espatifasse em ainda mais pedaços" (Jaffe, 2014, p. 1).

E demonstra que, em tempos de liquidez, as relações humanas se tornam fluidas, escassas, temerosas. Trancam-se os corações, trocam-se os afetos, pois "tudo o que é sólido se desmancha no ar". 


\section{O outro lado da sombra}

Romance de estreia de Mariana Portella, O outro lado da sombra adota forma de construção distinta, apesar da afinidade do tema. $\mathrm{O}$ texto se expressa em tom menor e melancólico, denso e forte, narrado em primeira pessoa pelo protagonista masculino Soren, em trama intimista. O tom, algumas vezes impostado e intelectualizado, faz com que ecoe, muito diretamente, na psique do personagem o primeiro nome do filósofo Kierkegaard, de quem o Soren do romance retoma a filosofia de vida, que repassa entre aspas ao leitor: "A vida só pode ser compreendida olhando-se para trás; mas só pode ser vivida olhando-se para frente" (Portella, 2014, p. 203).

Com um elenco de personagens no qual se desenvolve um triângulo amoroso, o texto trata de Soren (narrador em primeira pessoa), responsável pelo relato discutivelmente confiável pela centralização no eu, e Laura, com quem cultiva uma relação tensa, baseada em memória e esquecimento. Soren tem um irmão, Carlo, com quem se relaciona por pesados conflitos. Em meio a estes personagens, temos um pequeno círculo, não diria de figurantes, mas de figurações paralelas: Martin e a suicida Sofia.

O cerne de suas vidas difere bastante do cotidiano de um casamento desgastado que nos narra Anel de vidro. Aqui não se examinam a corrosão da instituição do matrimônio, nem seu naufrágio desgastante. Em $O$ outro lado da sombra, a maioria dos laços de afeto (entre amigos, entre enamorados e na relação dos personagens consigo mesmos) são fragilizados e fragmentados, além de revelarem, de modo claro e sem disfarces ao longo da narrativa, suas relações de amor e ódio, raiva, pena e inveja, sempre instáveis e ambíguas. Isto é um ponto importante, pois retira o texto da rigidez moral em geral mantida pela fachada hipócrita da vida burguesa.

O clima é muitas vezes onírico, pois passagens aparentemente "reais" e assustadoras (pelo tom sombrio e altamente melancólico) são resolvidas pela explicação de que frutificam de um sonho ou, melhor dizendo, de um pesadelo. $\mathrm{O}$ intertexto com Kierkegaard já traz inscrita essa tendência ao tom existencial nostálgico. Relembra-se neste momento do caso de amor e do noivado mal resolvido de Sören Kierkegaard com Regine Olsen, tratado por Lukács em magnífico capítulo de $A$ alma e as formas (1974). Kierkegaard foi um filósofo dinamarquês de formação teológica luterana severa. A partir de um relacionamento doentio imposto pelo pai, 
sentiu-se marcado por uma espécie de mão dura do destino, que teria tocado sua vida e teria sido - além de sua autorreflexão permanente e torturante - um dos motivos que o levaram a interromper, após um ano, o noivado com Regine Olsen, a quem parece ter amado para sempre, sugerindo que ela seria sempre a leitora implícita do que viria a escrever. Mas o clima denso e filosófico da obra de Kierkegaard não penetra - a não ser como referência breve - essa obra de Mariana Portella, mas a insere dentro da problemática de uma forma de preocupação com a filosofia da existência.

Crise e medo dos impedimentos dificultam, quando não impedem, o estabelecimento de elos lúcidos, de projetos em comum que desemboquem em união consistente, sem tantos altos e baixos. A perda de memória de Soren, que ocupa boa parte do texto e ocorre depois de um acidente, favorece o modo de estar do personagem, sempre marcado pela névoa da memória pouco clara e sob a forma de lacuna. Este estado elíptico afeta não apenas Soren como também Laura, que se torna para ele uma desconhecida de quem não consegue se lembrar. A insinuação da falta de sentido da vida, à qual se tem de dar sentido pelas ações, entre outros recursos do texto, sugere outro intertexto, não mais com Kierkegaard, mas com o mito de Sísifo, a partir do qual se produz um enclave da interpretação dos gregos, como a de Albert Camus, citado no texto. Cada um rola a sua pedra, dia a dia, pesadelo a pesadelo, como se vê na destruição da própria vida por Sofia, que se suicida, tanto como ocorre no sadomasoquismo não disfarçado das relações de amor e ódio e inveja de Carlo com o irmão Soren. Clausura e confinamento interpenetram-se em um mundo às vezes fantasmagórico no qual a sombra ofusca a claridade dos atos, dando lugar à perquirição solitária do eu interior.

Itália, Paris e Dublin dão um ambiente europeu ao relato de jovens cultos, que padecem de encarceramentos internos e de um niilismo que afasta o diálogo em prol da adoção da técnica do monólogo interior, que, claro, toma o caminho do solilóquio, pois conta com a presença do testemunho do outro, o leitor. A narrativa estabelece uma técnica rara, mas já existente no Hamlet, por exemplo, a do monólogo interior em exibição na dramaturgia elaborada dos eus. Soren, em dado momento, após o acidente, diz que tinha ido para Dublin encontrar-se consigo mesmo, pensando que o tempo enevoado daquela cidade, bem como sua vida mais rural, que não relembrava o cosmopolitismo de Roma e Paris, talvez lhe permitissem 
encontrar as chaves para o autoconhecimento, que supunha estarem escondidas e, quem sabe, estivessem dentro dele mesmo:

Aquela cidade era o cerne de tudo, o motivo da viagem e a meta final. Espremia a cuca como metade de uma laranja em um espremedor, até que toda a polpa estivesse liquefeita./Estava em Dublin viajando comigo mesmo, para rearrumar o armário das ideias, e queimar a raiz dos meus medos. Lembrava-me de ter saído do aeroporto, despedir-me de Laura e tomar o táxi, entrar na casa alugada e começar a fumar o cachimbo (Portella, 2014, p. 106).

É mesmo inexplicável o fato de que o fundo que se busca em si mesmo não tem fundo, jamais se atinge esse limite da essência do eu, possibilidade em que acreditava, por exemplo, Jean-Jacques Rousseau. Todavia, em $O$ outro lado da sombra, Soren percebe que não se atinge esse limite - o fundo - do eu. Por esta razão, a narrativa vai gradativamente estabelecendo uma correlação com o estranho e com o surrealismo. Em certo momento, o texto se intertextualiza com a filmografia de David Lynch, cineasta norte-americano conhecido por participar de uma filmografia de tendência surreal e bizarra, que realiza com um nível de qualidade que o tornou famoso não só no cinema, mas como diretor de séries para a televisão, como a marcante Twin Peaks (1990).

$\mathrm{O}$ texto mergulha mais de uma vez em um clima onírico. Este, em benefício da comunicabilidade com o leitor médio, acaba sendo "explicado" pelo uso do tema da perda das lembranças de Soren, em um capítulo bastante surrealista, no qual o leitor se perde à procura de um fio lógico sem encontrá-lo. A passagem, longa, é justificada adiante pelo fato de o personagem Soren acordar de um pesadelo, o que enfraquece um pouco o texto dessa estreante talentosa, pois isto dissolve a força do insólito, com o qual ela trabalha bem.

Nesse sentido, o romance de Mariana Portella distingue-se tanto do de Ana Luisa Escorel, quanto do de Elvira Vigna. No entanto, une-se aos outros dois ao acentuar o medo e a dificuldade afetiva de personagens, que não conseguem estabelecer laços que se desenrolem a contento, uma vez que isto lhes é impedido pelas inquietações em face das relações consigo mesmos e com os outros. Nas três narrativas, o mundo está sempre fora dos eixos, o que torna os textos bem interessantes, resolvendo-se em uma chave não realista, nem naturalista stricto sensu. 


\section{O que deu para fazer em matéria de história de amor}

A instabilidade marca a trajetória dos personagens do romance. Não por acaso, grande parte dos acontecimentos narrados acontece em trânsito, no não lugar, como chamado por Marc Augé: as ruas, os cafés, os aeroportos, as autoestradas - espaços públicos palpáveis, concretos, mas ao mesmo tempo fluidos pelo ir e vir de pessoas que não cessa de acontecer, pessoas que seguem anônimas, sempre vendo diante de si o cenário se transformando, o ambiente em metamorfose, mas arraigando-se mais e mais a solidão dos que por ali trafegam. $\mathrm{O}$ não lugar parece com os cenários voláteis e, nesse sentido, remete à solidão e à fragmentação das próprias pessoas que transitam o espaço urbano no mundo contemporâneo, até dentro de si mesmas, em suas vidas como personagens em isolamento.

Com linguagem cortante, em que se evita o sentimentalismo, a narrativa de Elvira Vigna constrói personagens como se para fazê-los expor uma visão de mundo cáustica e desiludida, sem arroubos de amor, visto que a devastação emocional os acompanha e obseda algumas vezes. O romance atém-se não só ao que é narrado, mas nele importa também o ato mesmo de escrever. Importa, enfim, "como fica a vida quando ela é escrita, anotada, reescrita por escrito" (Resende, 2014, p.1).

Enquanto, em O outro lado da sombra, de Mariana Portella, discute-se o pertencimento e lamenta-se sua perda e seu caráter fugidio, em Vigna, ele é buscado. No texto $O$ que deu para fazer em matéria de amor, a narradora inventa uma história para entender a própria história. A narradora do livro debruça-se sobre a vida de duas pessoas já mortas, Rose e Arno. Não só o apartamento em que os dois moraram, e que ela agora precisa esvaziar e arrumar, mas ela própria, a narradora, precisa lançar coisas suas, internas, para fora de si. Há nisto um jogo consigo mesma: ela quer entender a vida daquelas pessoas para entender sua própria vida, para esvaziar os entulhos internos que foi acumulando ao longo de décadas de convivência com Roger, filho de Rose.

Em O que deu para fazer em termos de história de amor, a literatura em si mesma é uma atividade dessacralizada, não vista, como em Luiz Ruffato, por exemplo, como meio de transformação social. ${ }^{5}$ Se para Ruffato a

\footnotetext{
${ }^{5}$ Como se pôde ver na leitura de um debate mantido pelos dois, Ruffato e Vigna, em uma mesa do Café Literário da Bienal do Livro no Paraná, em 2010, que culminou por ser uma das mesas mais
} 
literatura tem uma carga de missão e compromisso, para Vigna, a literatura passa ao largo dessa interpretação, configurando-se como algo efêmero, que "balança", mas não muda nenhuma estrutura (Vigna, 2010).

Vigna, como Escorel, trabalha em surdina o sentimento do medo e, do mesmo modo, faz baixar o tom do melodrama, do sentimentalismo tão comum ao mundo latino-americano. Ela introduz um "menos que vale mais", um relaxamento da tensão não para paralisá-la, mas para deixá-la mais forte e contundente. Ao lhe perguntarem se achava que seu livro Nada a dizer era uma "tragédia contemporânea", Elvira Vigna responde que "a tragédia contemporânea é o não amor" (Vigna, 2014). O sentido de urgência e de importância da vida é trocado por um sinal da escrita: "Nada aconteceu. Não há história alguma. Nada que os destaque, que nos destaque. Somos todos sem sentido algum mesmo, em nossas vidinhas em que nada acontece" (Vigna, 2012, p. 203). E nos três romances, o sentido cético diante da existência é uma forma de revelar que a "vida, ainda que valha mais do que as palavras, não vale sem elas" (Helena, 2010, p. 11).

Tão diferentes são as nossas três autoras e seus textos peculiares, como se pode notar ao longo da exegese feita. Espera-se que tenha ficado claro aos leitores - tanto para aqueles que já as conhecem e leram os textos que foram abordados como matéria de reflexão sobre o medo, a fragilidade e a solidão no difícil panorama atual, quanto para os que as desconhecem ainda - que tais obras estão aqui reunidas por criarem, cada uma, pontos nucleares de desenvolvimento que, entre si comparados, configuram um paradigma importante para a literatura brasileira cujo regime não é, estrito senso, o do realismo, do neorrealismo, do regionalismo ou do neonaturalismo revigorados no fim do século XX e na virada do século XXI.

Com a prosa magnífica de Laura Escorel, Anel de vidro, de um minimalismo que diz tanto, ergue-se a discussão alegórica - no sentido benjaminiano de fazer falar o outro reprimido pela história do vencedor, no caso tanto o patriarcalismo ancestral que ultrapassa os limites do Brasil, quanto o comportamento de alguns personagens, a sogra, por exemplo, em busca de valores cada vez mais apegados ao sucesso econômico, ao louvor/amor ao poder, colocado acima dos outros valores básicos de um humanismo hoje posto à prova e tido como desgastado e, talvez, inútil para enfrentar os novos tempos que chegam. Escorel traça, numa narrativa de

vivas e agradáveis, segundo quem assistiu ao diálogo entre os dois, pois, apesar de se oporem em relação ao que a literatura significa, conseguiram manter uma conversa ágil, intensa, que muito rendeu. 
múltiplos focalizadores, ${ }^{6}$ um texto em dialogismo, que não se conforma em lidar com as diferenças de modo maniqueísta, preferindo dialetizá-las, sem buscar uma síntese que acalme as consciências. Antes, enfatiza, na angústia que se entrevê nos quatro personagens que funcionam como elementos fulcrais do paradigma, o clima de medo, de solidão amorosa com o outro e consigo mesmos, a fragmentação e o desmantelo de almas em desassossego, na insatisfação que embasa o idealismo levado a uma corrosão cética. Como nos diz Walnice Nogueira Galvão, Laura Escorel é um vento novo no cenário nacional, embora a ficcionista seja alguém que se lançou na literatura tardiamente.

Na obra escolhida de Mariana Portella, O outro lado da sombra, medo e solidão são temas transformados em formas estéticas, já que configuram estruturas mentais, mais que simples conteúdos legíveis em primeira instância. $\mathrm{O}$ aprofundamento a que é submetida a semântica deve muito à escolha da sombra, do fantástico, do clima onírico que ressalta o material inconsciente e assinala a trajetória dos personagens. A recuperação - que merecia um empenho maior - da figura e da obra dilemática de Kierkegaard 7 é um ganho sobremaneira importante dessa escritora jovem, que o importa como uma nova possibilidade da escrita do infinito desejo de duvidar, de cogitar, sem saber se haverá saídas, numa ficção na qual o que de fato importa é vislumbrar hipóteses para a caminhada, que não se fecha na preguiça das soluções tranquilizadoras.

Elvira Vigna é uma mestra da narrativa sincopada, da surpresa, da habilidade com que joga com o não lugar, questão bem desenvolvida por Marc Augé. Seu texto tem a agilidade das imagens do dentro e do fora, muitas vezes um bar, espécie de setting de observação, olho câmera da narrativa que vai apertando o cerco, mas que não entrega fácil a constituição interna dos personagens sofredores que constrói com vigor e rigor. Sua narrativa $O$ que deu para fazer em matéria de história de amor foi o texto escolhido para representar sua competente e vasta ficção, justamente porque nele se manifesta, mais do que em outros, esse movimento de observar, fixar o olho, ir para dentro, devassar a alma, que se recusa a entregar-se e devolve a pegada do olhar, exigindo do leitor um esforço de decodificação que o faz um coautor, jamais um leitor vampiro,

\footnotetext{
${ }^{6}$ Como a pesquisadora holandesa conceitua o termo em seu importante Narratology, ainda não traduzido entre nós (Bal, 1985).

${ }^{7}$ Filósofo do dilema ele mesmo, sempre na faca só lâmina do ou... ou..., isto é, modificador do melodrama do sofrimento do romantismo menor, construindo uma poética do desassossego.
} 
que se nutre semanticamente de um pretenso caldo de significado narrativo. Grande escritora, Vigna recolhe também a questão do medo afinal, a morte, um crime velado, a sedução pelo perverso no caminho da sexualidade são habilmente reunidos, sem maniqueísmos, moralismos, nem demolições diretas do preconceito social. O que deu para fazer em matéria de história de amor, em apuro técnico e pauta também cética, consagra o desatar dos nós, a desmontagem dos anéis de vidro, das armadilhas do amor e do ideal que se revela impossível de ser atingido. Os três romances, cada um a seu modo e com a sua própria intensidade, são fundamentais para se avaliar o que de melhor tem sido apresentado por narrativas que podem ser tidas como ficções do desassossego (Helena, 2010), denominação que convém expandir para abrigar os romances aqui estudados, os quais confirmam ter o desassossego lugar de proeminência na ficção dessas três mulheres inquietas.

\section{Referências}

AGAMBEN, Giorgio (2009). O que é contemporâneo? E outros ensaios. Tradução de Vinicius Castro Honesko. Chapecó: Argos.

BAL, Mieke (1985). Narratology. Toronto: University of Toronto Press.

BAUMAN, Zygmunt (2004). Amor líquido. Sobre a fragilidade dos laços humanos. Tradução de Carlos Alberto Medeiros. Rio de Janeiro: Zahar.

BAUMAN, Zygmunt (2008). Medo líquido. Tradução de Carlos Alberto Medeiros. Rio de Janeiro: Zahar.

BENJAMIN, Walter (2000). Paris capitale du XXXe siècle. Le livre des passages. Tradução de Jean Lacoste. 3. ed. Paris: du Cerf.

ESCOREL, Ana Luíza (2013). Anel de vidro. Rio de Janeiro: Ouro sobre Azul.

GALVÃO, Walnice Nogueira (2014). Era pouco e se acabou. Resenha de Anel de vidro, romance de Ana Luiza Escorel. São Paulo, Folha de S. Paulo, Ilustríssima, p. 4,9 fev.

HELENA, Lucia (2010). Ficções do desassossego: fragmentos da solidão contemporânea. Rio de Janeiro: Contra Capa.

HUMPHREY, Robert (1976). O fluxo da consciência. Um estudo sobre James Joyce, Virgínia Woolf, Dorothy Richardson, William Faulkner e outros. 
Tradução de Gert Meyer. Revisão Técnica de Afrânio Coutinho. São Paulo: McGraw-Hill do Brasil.

JAFFE, Noemi (2014). Anel de vidro. Folha de S. Paulo, Ilustríssima, p. 1, 30 nov. LISPECTOR, Clarice (1965). Laços de família. 3. ed. Rio de Janeiro: Ed. do Autor. LLANSOL, Maria Gabriela (1977). O livro das comunidades. Geografia de rebeldes. Porto: Afrontamento.

LUKÁCS, Georg (1974). L'âme et les formes. Tradução de Guy Haarscher. Paris: Gallimard.

PORTELLA, Mariana (2014). O outro lado da sombra. Rio de Janeiro, Rocco.

RESENDE, Beatriz (2014). Elvira Vigna acompanha personagem indiferente ao mundo ao seu redor. $O$ Globo, 26 out. On-line. Disponível em: <http://goo.gl/kAnAA5>. Acesso em: 22 dez. 2014.

VIGNA, Elvira (2012). O que deu para fazer em matéria de história de amor. São Paulo: Companhia das Letras.

VIGNA, Elvira (2014). Café Literário: Elvira Vigna e Luiz Ruffato. Interrogação, 2010. On-line. Disponível em: <http://interrogacao.com.br/2010/10/cafeliterario-elvira-vigna-e-luiz-ruffato/\#>. Acesso em: 22 dez. 2014.

Recebido em janeiro de 2016.

Aprovado em março de 2016.

\section{resumo/abstract/resumen}

\section{A queda das ações no mercado dos afetos: medo, amor e solidão em Ana Luiza Escorel, Mariana Portella e Elvira Vigna}

Lucia Helena

Estudo da situação dos personagens de três romances escritos por Ana Luisa Escorel, Mariana Portella e Elvira Vigna, examinados sob o impacto da crise contemporânea dos afetos na sociedade da globalização. $\mathrm{O}$ artigo aborda os romances: Anel de vidro (Escorel), O outro lado da sombra (Portella); O que deu para fazer em matéria de história de amor (Vigna).

Palavras-chave: personagens, globalização, subjetividade, Ana Luisa Escorel, Mariana Portella, Elvira Vigna. 
The fall of the stock market of affects: fear, love and loneliness in Ana Luiza Escorel, Mariana Portella and Elvira Vigna

Lucia Helena

This essay analyzes of the construction of characters in three contemporary Brazilian novels written by Ana Luisa Escorel (Anel de vidro), Mariana Portella $(O$ outro lado da sombra) and Elvira Vigna ( $O$ que deu para fazer em matéria de história de amor). These novels are examined from the perspective of the crisis of affects in globalized society.

Keywords: characters, globalized society, subjectivity, Ana Luisa Escorel, Mariana Portella, Elvira Vigna.

La caída del mercado de valores de los afectos: el miedo, el amor y la soledad en Ana Luiza Escorel, Mariana Portella y Elvira Vigna

Lucia Helena

Estudio de la situación de los personajes en tres novelas escritas por Ana Luisa Escorel, Mariana Portella y Elvira Vigna, que se examinan bajo el impacto de la crisis contemporánea de los afectos en la sociedad globalizada. El artículo analiza las novelas: Anel de vidro (Escorel), O outro lado da sombra (Portella); O que deu para fazer em matéria de história de amor (Vigna).

Palabras clave: personajes, globalización, subjetividad, Ana Luisa Escorel, Mariana Portella, Elvira Vigna. 